\title{
Negative and Positive Impacts of Rape Straw Returning on the Roots Growth of Hybrid Rice in the Sichuan Basin Area
}

\author{
Xuechun Wang ${ }^{1, *,+}$, Naseem Samo ${ }^{1}{ }^{\oplus}$, Changkun Zhao ${ }^{1,+}{ }^{\dagger}$, Hongni Wang ${ }^{1}$, Guotao Yang ${ }^{1}$, \\ Yungao $\mathrm{Hu}^{1, *}$, Youlin Peng ${ }^{1}$ (D) and Fahd Rasul ${ }^{2}$ (D) \\ 1 College of life science and engineering, Southwest University of science and technology, Mian Yang, \\ Sichuan 621010, China; samonaseem@hotmail.com (N.S.); 18308462683@139.com (C.Z.); \\ hongni2005@sohu.com (H.W.); yangguotao2377893@163.com (G.Y.); youlinp@hotmail.com (Y.P.) \\ 2 Agweathernet, Washington State University, Prosser, WA 99350, USA; drfahdrasul@gmail.com \\ * Correspondence: xuechunwang@swust.edu.cn (X.W.); huyungao@swust.edu.cn (Y.H.) \\ + These authors contributed equally to this work and should be considered co-first authors.
}

Received: 28 September 2019; Accepted: 24 October 2019; Published: 28 October 2019

\begin{abstract}
Incorporating oilseed-rape straw in soil is one of the effective methods for enhancing the use efficiency of agricultural resources in the rape-rice rotation system. However, the impacts of oilseed-rape straw incorporation on root growth and dynamic changes in soil are still unclear. In order to provide a deeper understanding of the oilseed rape straw return on rice growth and productivity, the experiment was conducted in the field and in a specially-designed pots system from 2016 to 2017 by means of two straw returning methods and four straw returning amounts. In the early stage of rice growth (0-36 days after rice transplanting) the straw returning treatments decreased $1.0-8.6 \mathrm{mg} /$ plant in bleeding density and $0.10-6.11,0.06-0.31$, and $0.52-0.84 \mu \mathrm{mol} /(\mathrm{g} \mathrm{h})$ in the activity of glutamine synthetase (GS), glutamic-oxalacetic transaminase (GOT), and glutamic-pyruvic transaminase (GPT), respectively. Oilseed rape straw returned by mulching induced negative impacts on new germinating roots in $0-10 \mathrm{~cm}$ of soil, while the negative impacts were observed on roots in $10-30 \mathrm{~cm}$ of soil for straw returned by plowing. In the later stage of rice growth (56-75 days after rice transplanting), oilseed rape straw returning produced some positive impacts on rice roots, which enhanced the yield of rice. Conclusively, our findings suggested that dynamic root growth and the activity of root enzymes are two major factors behind the slow reviving of rice after transplanting in the straw returning field. Plowing is a more appropriate method of straw returning than mulching in the rape-rice rotation system in the Sichuan basin area, with a straw incorporation rate of $3.0 \mathrm{t} / \mathrm{hm}^{2}$.
\end{abstract}

Keywords: root morphology; root physiology; rice; oilseed rape; yield; straw incorporation

\section{Introduction}

Incorporating oilseed-rape straw in soil is one of the effective methods for enhancing the use efficiency of agricultural resources in the rape-rice rotation system [1]. Mulching straw over the field and plowing straw into deep soil are two primary methods generally operated by farmers to return oilseed-rape straw back to the soil in rape-rice rotation areas [2]. Mulching treatment is appropriate for hilly areas due to lesser usage of machinery, while plowing treatment is suitable for plain areas where the mechanization is relatively higher [3,4]. Previous research has explored that continuous straw incorporation in soil built a better growth environment for rice when considering long periods, by means of increasing the nitrogen, phosphorus, potassium [5-7], and organic matter content of the soil [8-10]. Most of the earlier studies reported that straw incorporation enhanced rice yield in rape-rice rotation fields when considering long periods. Straw incorporation technology, either by 
mulching or plowing, has been widely implemented in the Sichuan Basin area of China [11] and other rape-rice rotation regions in the world over the last 10 years $[9,12,13]$, which significantly increased the use efficiency of crop's straw in rape-rice rotation fields. However, a delay of reviving after transplanting and a reduction of grain yield were found in some rape-rice rotation fields [2,14], where lots of straw were returned back to the soil. This instability of rice yield impeded the application of straw returning technology in the rape-rice rotation region. Therefore, it is crucial to comprehend the reasons that lead to the slow revival of rice and reduction in the grain yield after transplanting to straw incorporated fields.

Former studies reported several reasons for the late reviving of rice in straw incorporated fields, though most of them agreed that straw incorporation has a significant influence on rice growth and grain yield $[8,9,11]$. However, the impacts of oilseed-rape straw incorporation on root growth and dynamic changes in soil are still unclear. The earlier investigation unveiled that the rice roots grow slowly and appear blackish in color [15], which indicated that root growth and dynamic changes might be one of the important factors for the delay of rice revival and reduction of yield in oilseed-rape straw-incorporated fields.

The objectives of this paper are to clarify the impacts of straw incorporation on root growth, root bleeding, and root distribution to explain why rice revives slowly after transplanting to straw incorporated fields from the perspectives of root growth and dynamic changes in soil.

\section{Materials and Methods}

\subsection{Study Area}

The present study was carried out in Mianyang city, which is located in the northwest part of the Sichuan Basin area, in the middle and upper reaches of the Fujiang River. It has a typical subtropical monsoon climate with an annual rainfall of $826-1417 \mathrm{~mm}$, an annual temperature of $14.7-17.3^{\circ} \mathrm{C}$, and a frost-free period of 252 and 300 days. The soil of the corresponding region is typical clay-loam soil with a bulk density of $1.29 \mathrm{~g} / \mathrm{cm}^{3}$ in which the organic matter content is $28.6 \mathrm{~g} / \mathrm{kg}$, total nitrogen content is $1.68 \mathrm{~g} / \mathrm{kg}$, total phosphorus is $0.37 \mathrm{~g} / \mathrm{kg}$, and total potassium is $1.86 \mathrm{~g} / \mathrm{kg}$. As the primary food crops, rice and oilseed rape constitute a Paddy-dryland rotation system in this area. Oilseed rape is cultivated from late September to early May, and rice is cultivated from April to September. Rice is generally sowed in seedbed during April and then transplanted to the field by machinary during early May.

\subsection{Experimental Design}

The experiment was carried out in the field and in a specially-designed pots system (China National Invention Patent, ZL201610221861.1) from 2016 to 2017. Two oilseed rape straw returning methods, mulching over the soil surface and plowing into the soil with 4 straw amounts, were used in this experiment (Table 1). All oilseed rape straw was crushed by a special machine (Jinyang 4LZ-1.2, Deyang Jinxing agricultural equipment Co. Ltd.) and stored for further use. The field experiment was performed by split block experimental design, 8 treatments with 3 replications were arranged in 24 plots. The area of each plot was $160 \mathrm{~m}^{2}(16 \mathrm{~m} \times 40 \mathrm{~m})$ with 4 subplots of $40 \mathrm{~m}^{2}(4 \mathrm{~m} \times 10 \mathrm{~m})$; four straw amounts were incorporated in four subplots of each plot. A $0.5 \mathrm{~m}$ wide and $0.3 \mathrm{~m}$ high ridge was made between plots, and a plastic film ( $0.5 \mathrm{~m}$ deep) was coated over the ridge to prevent flooding from one plot to another and to keep the experiment results out of the impacts of nutrition transferring from one plot to another by runoff and infiltration. For the root growth and root distribution analysis, a pot planted experiment was designed with 8 treatments and 3 replications, which were distributed in 144 pots. The experiment was conducted using the same quality rice and the same soil from the experiment field.

Deyou4727, a hybrid rice variety was chosen for this experiment, seeds were sowed in early April. In order to avoid the impacts of seedling quality on root growth, strong and healthy seedlings with similar quality and 2 tillers were selected and transplanted to the field plots and in the pots during the 
mid of May. The rice was supplied with $180 \mathrm{~kg} / \mathrm{hm}^{2}$ of nitrogen $(\mathrm{N}), 225 \mathrm{~kg} / \mathrm{hm}{ }^{2}$ of potassium $(\mathrm{KCl})$, and $120 \mathrm{~kg} / \mathrm{hm}^{2}$ of phosphorus $\left(\mathrm{P}_{2} \mathrm{O}_{5}\right)$ during growth season. Nitrogen was (urea) applied as a base, tiller, and panicle fertilizer in the ratio of 5:3:2; potassium fertilizer was (potassium chloride) applied as a base and panicle fertilizer in the ratio of 1:1; phosphorus fertilizer was (calcium superphosphate) applied as a base fertilizer along with soil tillage before transplanting rice. Shallow water irrigation was used at the tillering, booting, and full filling stage (1:1:1), and no irrigation was used at other growth periods of the rice. All management, including transplanting, fertilization, and irrigation, was the same for the field experiment and pots planted experiment.

Table 1. Detailed information on oilseed rape straw treatments.

\begin{tabular}{ccccccccc}
\hline & $\mathbf{M U}_{\mathbf{0}}$ & $\mathbf{M U}$ & $\mathbf{M U}_{\mathbf{2}}$ & $\mathbf{M U}_{3}$ & $\mathbf{P L}_{\mathbf{0}}$ & $\mathbf{P L}_{\mathbf{1}}$ & $\mathbf{P L}_{2}$ & $\mathbf{P L}_{3}$ \\
\hline Straw returning amount & $0.0 \mathrm{t} / \mathrm{hm}^{2}$ & $1.5 \mathrm{t} / \mathrm{hm}^{2}$ & $3.0 \mathrm{t} / \mathrm{hm}^{2}$ & $4.5 \mathrm{t} / \mathrm{hm}^{2}$ & $0.0 \mathrm{t} / \mathrm{hm}^{2}$ & $1.5 \mathrm{t} / \mathrm{hm}^{2}$ & $3.0 \mathrm{t} / \mathrm{hm}^{2}$ & $4.5 \mathrm{t} / \mathrm{hm}^{2}$ \\
\hline MU; represents the straw mulching over the soil surface, and PL represents the straw plowing into soil.
\end{tabular}

\subsection{Samples and Measurement}

Ten plants were selected to record the total number of tillers each 10-12 days until 115 days after rice transplanting. Five plants were taken as the samples to calculate the dry weight of shoot each 0-12 days until 75 days after rice transplanting. After maturity, 10 plants of rice were collected from each plot to calculate the rice yield and the yield component.

Once rice transplanted, roots were sampled from $0-10 \mathrm{~cm}, 10-30 \mathrm{~cm}$, and $30-50 \mathrm{~cm}$ soil layers each 10-12 days from the pots system until 75 days after rice transplanting. The length and weight of roots were measured, and the number of roots was counted in each soil layer. At the same time, 10 typical plants were chosen in the experimental field to determine the bleeding amount per plant. The SS content, as well as the activity of glutamic-oxalacetic transaminase (GOT), glutamic-oxalacetic transaminase (GPT), and glutamine synthetase (GS) were measured in roots bleeding at 36 days and 65 days after transplanting. Five typical plants were selected and harvested to measure the yield component of each treatment and $15 \mathrm{~m}^{2}$ of rice from each plot harvested by hand to measure the yield.

For the root sampling, three inner pots were taken out from large external pots and cut into 3 parts, the top layer $(0-10 \mathrm{~cm}$ depth), the middle layer $(10-30 \mathrm{~cm})$, and the bottom layer $(30-50 \mathrm{~cm})$. All roots were washed and picked out from different parts, and root length and root weight (fresh) were measured, and the number of roots was counted for each part. Root length and root weight were measured by a standard ruler and 1/1000 balance; if $60 \%$ of the length of the root appeared blackish or brownish, it was calculated as a black root, and the rest were calculated as white roots; the roots shorter than $1 \mathrm{~cm}$ in length or decomposed were not calculated in root length and root weight. Root bleeding was collected by the cotton traps method [16], SS was performed according to Hu et al. [17], GOT activity was measured through the method of Sax et al. [18], and GPT and GS activity was tested via the methods of Zhong et al. [19] and Yu and Zhang [20], respectively.

\subsection{Data Analysis}

The average values were calculated based on 3 biological replications. When ANOVAs returned a significant result, the means were compared with Fisher's LSD test $(p<0.05)$ in SPSS (version. 20, Chicago, IL, US). The correlations between root growth, enzyme activity, and rice yield were analyzed by the Pearson correlation method in SPSS (version. 20, Chicago, IL, USA).

\section{Results}

\subsection{Impacts of Straw Incorporation on the Tillering Dynamics of Rice}

During the early stages (0-36 days after transplanting), straw incorporation has a negative impact on tiller growth (Figure 1). In a comparison of $\mathrm{MU}_{0}$, the tiller number of $\mathrm{MU}_{1}, \mathrm{MU}_{2}$, and $\mathrm{MU}_{3}$ decreased 1.0-3.0 tillers $(p<0.05)$; meanwhile, the tiller number of $\mathrm{PL}_{1}, \mathrm{PL}_{2}$, and $\mathrm{PL}_{3}$ decreased 1.0-2.4 tillers than 
$\mathrm{PL}_{0}(p<0.05)$. In either 2016 or in 2017, the tiller number of $\mathrm{PL}_{3}$ was near to 0 ; these results indicated that a plenteous amount of straw $\left(4.5 \mathrm{t} / \mathrm{hm}^{2}\right)$ caused a part of the rice tillers to die in the early stage of rice growth.
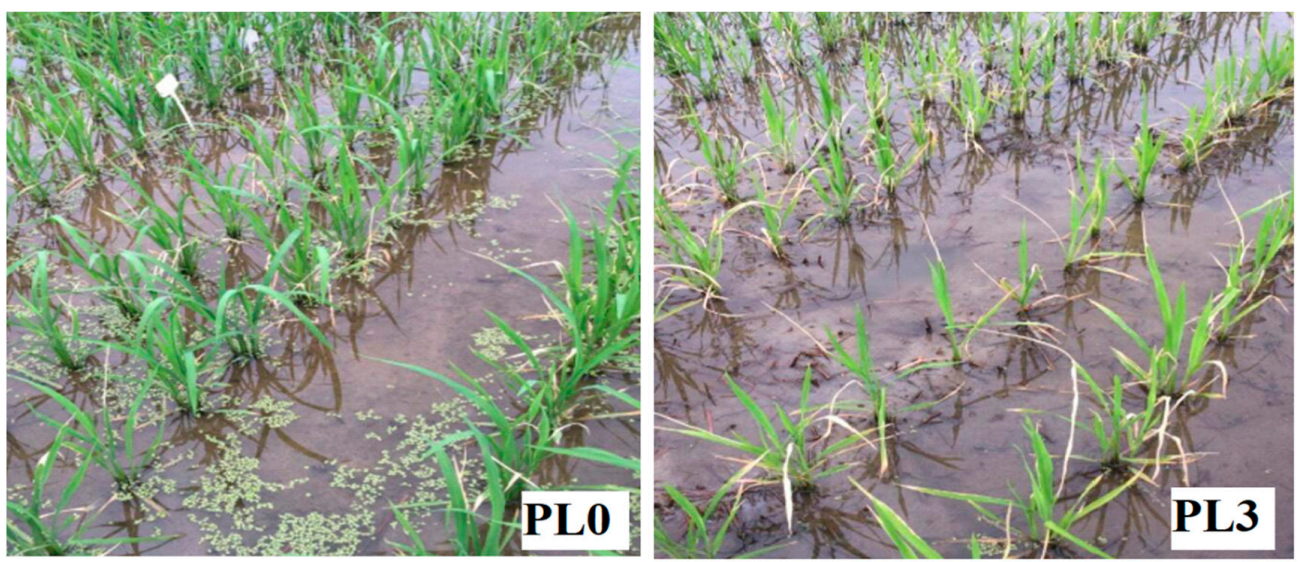

Figure 1. Dynamic changes of rice tillers without straw treatment $\left(\mathrm{PL}_{0}\right)$ and under straw treatments $\left(\mathrm{PL}_{3}\right)$.

Either by mulching or plowing, straw incorporation has a positive impact on the tiller number during the tillering stage of rice growth. As compared to $\mathrm{MU}_{0}$, the tiller number of $\mathrm{MU}_{1}, \mathrm{MU}_{2}$, and $\mathrm{MU}_{3}$ decreased 1.2 and increased 1.1 and 0.4 tillers respectively; whereas, compared with $\mathrm{PL}_{0}$, the tiller number of $\mathrm{PL}_{1}, \mathrm{PL}_{2}$, and $\mathrm{PL}_{3}$ increased 2.0, 2.6, and 2.5 tillers, respectively (Figure 2). Though the maximum tillers of $\mathrm{MU}_{3}$ and $\mathrm{PL}_{3}$ were higher than that of $\mathrm{MU}_{2}$ and $\mathrm{PL}_{2}$; however, the effective tiller number was nearly the same. An ANOVA analysis (Supplementary Materials) showed that the number of tillers of $M_{2}$ was significantly higher than $M_{3}$, however, the effective tillers of $M_{2}$ were not significantly higher than $\mathrm{MU}_{3}$, and similar results were observed for $\mathrm{PL}_{2}$ and $\mathrm{PL}_{3}$. These results might have bee caused by the self-regulating of the population in a rice field.
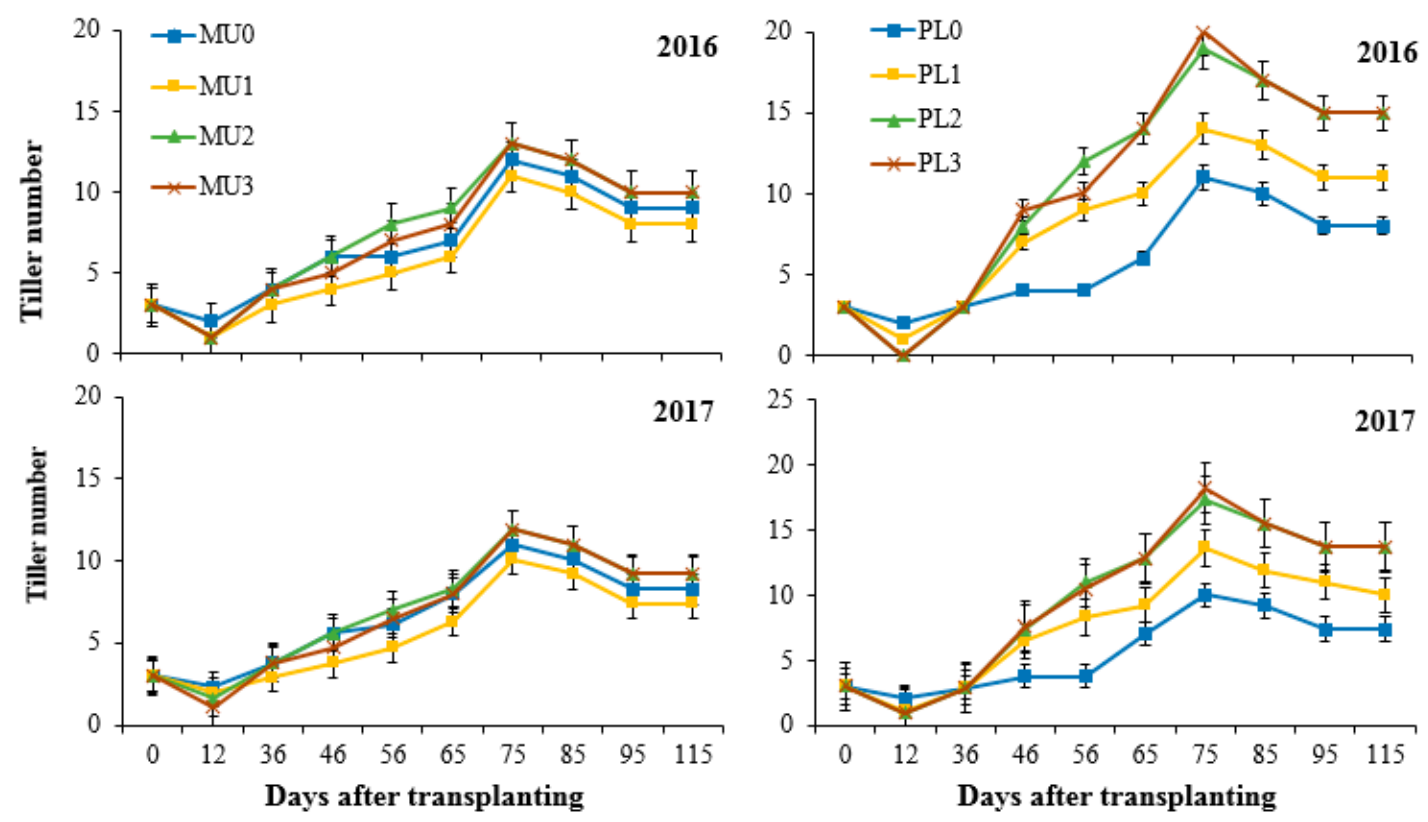

Figure 2. Dynamic changes of rice tillers under different straw incorporation treatments during 2016 and 2017. $\mathrm{MU}_{0}, \mathrm{MU}_{1}, \mathrm{MU}_{2}$, and $\mathrm{MU}_{3}$ represent $0.0 \mathrm{t} / \mathrm{hm}^{2}, 1.5 \mathrm{t} / \mathrm{hm}^{2}, 3.0 \mathrm{t} / \mathrm{hm}^{2}$, and $4.5 \mathrm{t} / \mathrm{hm}^{2}$ of straw, respectively, which were incorporated in soil by a mulching method. Whereas $\mathrm{PL}_{0}, \mathrm{PL}_{1}, \mathrm{PL}_{2}$, and $\mathrm{PL}_{3}$ represent $0.0 \mathrm{t} / \mathrm{hm}^{2}, 1.5 \mathrm{t} / \mathrm{hm}^{2}, 3.0 \mathrm{t} / \mathrm{hm}^{2}$, and $4.5 \mathrm{t} / \mathrm{hm}^{2}$ of straw, respectively, which were incorporated in soil by a plowing method. Impacts of straw incorporation on the dynamics of root distribution. 
In appropriate amounts, straw returning did not produce significant negative impacts on the total length and fresh weight of rice roots, while the total length and fresh weight of roots decreased significantly when excessive straw was incorporated into the soil (Figure 3), either by mulching or by plowing, during the early stage of rice growth (0-36 days after transplanting). In comparison of $\mathrm{MU}_{0}$, the length of rice roots in $\mathrm{MU}_{3}$ decreased $5 \mathrm{~cm} / \mathrm{d}(p<0.05)$, and its fresh weight reduced $0.05 \mathrm{~g} / \mathrm{d}$ $(p<0.05)$; while there was no significant difference among $\mathrm{MU}_{0}, \mathrm{MU}_{1}$, and $\mathrm{MU}_{2}$ (Figure $4 \mathrm{~A}, \mathrm{C}$ ), similar results were found for plowing treatments (Figure 4B,D). The root shoot ratios of $\mathrm{PL}_{3}$ and $\mathrm{MU}_{3}$ are lower than those of $\mathrm{PL}_{0}$ and $\mathrm{PL}_{3}$ at 12 days after rice transplanting (Table 2). Further analysis (Supplementary Materials) showed that straw incorporation by mulching produced a significant negative impact on root length in the $0-10 \mathrm{~cm}$ soil layer, while this negative impact reached the $10-30 \mathrm{~cm}$ soil layer for the excessive straw mulching treatment. Straw returning by plowing caused a significant reduction in root length in the $10-30 \mathrm{~cm}$ soil layer in comparison to $\mathrm{PL}_{0}$, while this negative impact reached the 30-50 cm soil layer for the excessive straw plowing treatment.

During the late stage of rice growth (56-75 days after transplanting), the impacts of straw-returning on the length and fresh weight of rice root was different between different straw returning methods (Figure 4). In comparison of $\mathrm{MU}_{0}$, the root length of $\mathrm{MU}_{1}, \mathrm{MU}_{2}$, and $\mathrm{MU}_{3}$ decreased 5, $15(p<0.05)$, and $20 \mathrm{~cm} / \mathrm{d}(p<0.05)$, respectively, with the reduction in fresh weight of $0.07,0.22(p<0.05)$, and $0.14 \mathrm{~g} / \mathrm{d}$ $(p<0.05)$; while the root length of $\mathrm{PL}_{1}, \mathrm{PL}_{2}$, and $\mathrm{PL}_{3}$ increased $56(p<0.05), 75(p<0.05)$, and $80 \mathrm{~cm} / \mathrm{d}$ $(p<0.05)$, respectively, with the increase in fresh weight of $0.39(p<0.05), 1.00(p<0.05)$, and $0.90 \mathrm{~g} / \mathrm{d}$ $(p<0.05)$, compared with $\mathrm{PL}_{0}$. The root shoot ratios of $\mathrm{PL}_{3}$ and $\mathrm{MU}_{3}$ are higher than those of $\mathrm{PL}_{0}$ and $\mathrm{PL}_{3}$ at 75 days after rice transplanting (Table 2). Further analysis (Supplementary Materials) showed that straw incorporation by mulching produced a significant negative impact on the root length in the 0-10 cm soil layer and a positive impact in the 10-30 cm soil layer. Straw returning by plowing caused a significant increase of root length in the $0-10 \mathrm{~cm}$ and $10-30 \mathrm{~cm}$ soil layers, in comparison to $\mathrm{PL}_{0}$.
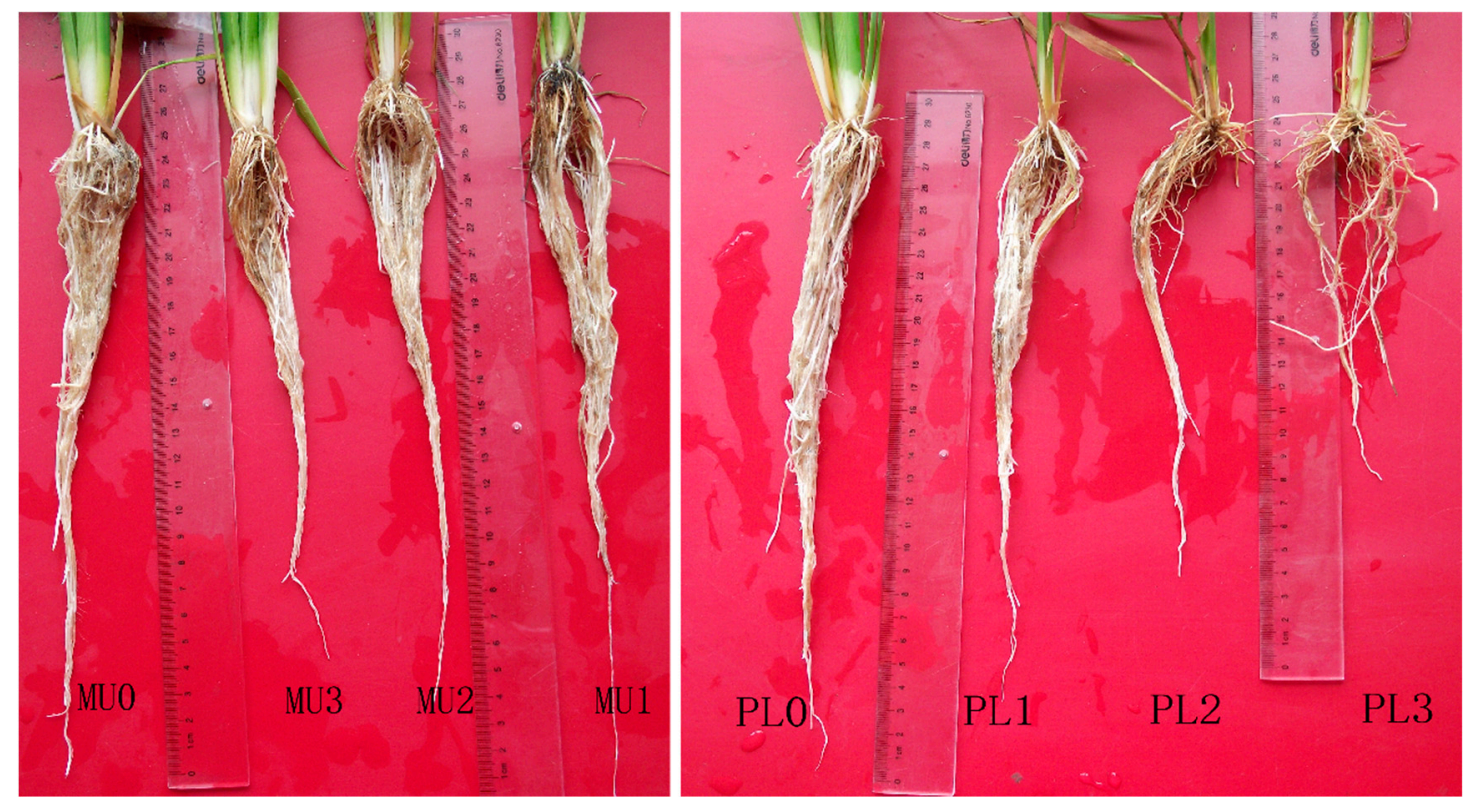

Figure 3. Comparison of root length of rice under different straw returning treatments, $\mathrm{MU}_{0}, \mathrm{MU}_{1}$, $\mathrm{MU}_{2}$, and $\mathrm{MU}_{3}$ represent $0.0 \mathrm{t} / \mathrm{hm}^{2}, 1.5 \mathrm{t} / \mathrm{hm}^{2}, 3.0 \mathrm{t} / \mathrm{hm}^{2}$, and $4.5 \mathrm{t} / \mathrm{hm}^{2}$ of straw, respectively, which were incorporated into the soil by a mulching method. Whereas $\mathrm{PL}_{0}, \mathrm{PL}_{1}, \mathrm{PL}_{2}$, and $\mathrm{PL}_{3}$ represent $0.0 \mathrm{t} / \mathrm{hm}^{2}, 1.5 \mathrm{t} / \mathrm{hm}^{2}, 3.0 \mathrm{t} / \mathrm{hm}^{2}$, and $4.5 \mathrm{t} / \mathrm{hm}^{2}$ of straw, respectively, which were incorporated in soil by a plowing method. 

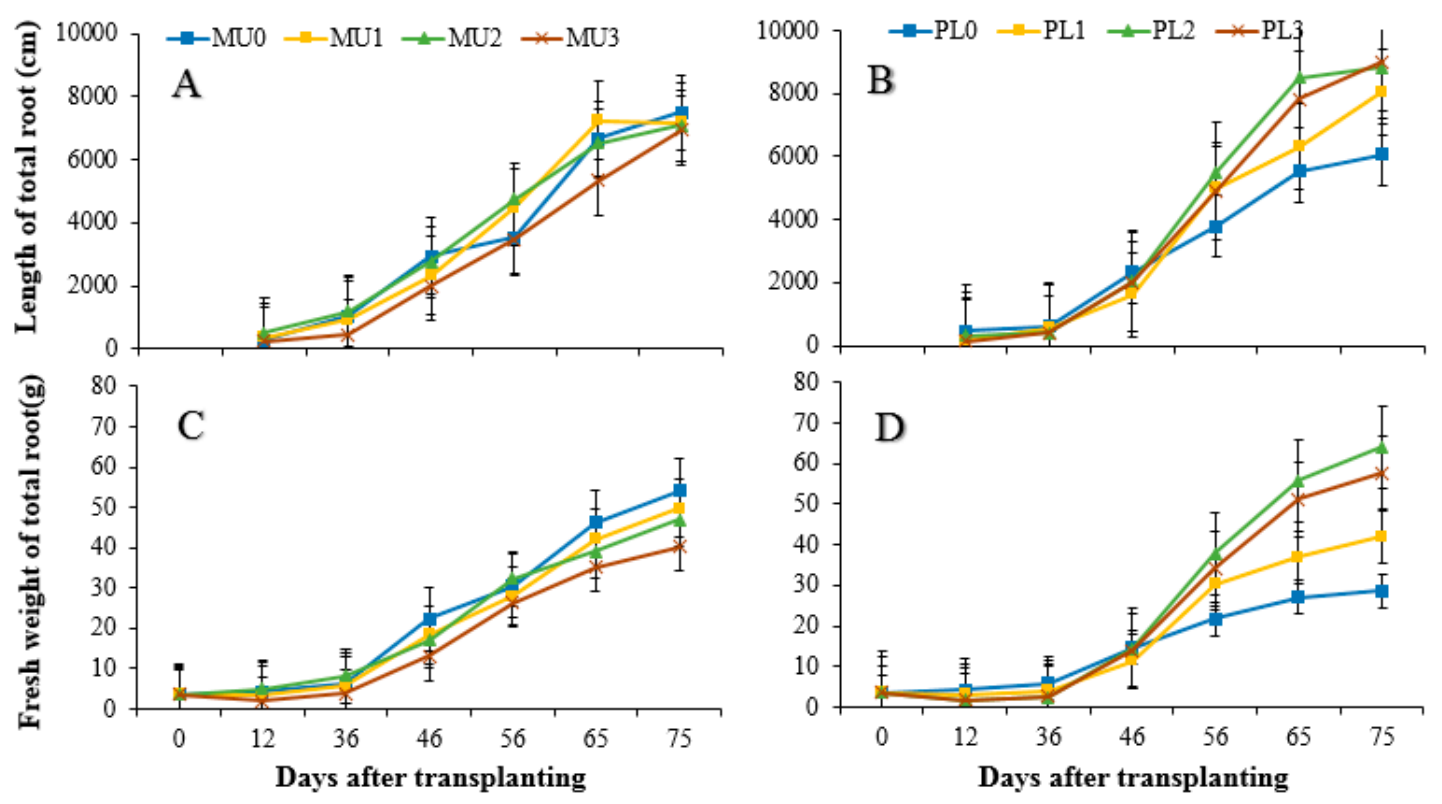

Figure 4. Comparison of total length and weight of rice root under different straw returning treatments. $\mathbf{A}$ and $\mathbf{B}$ are the total root length of mulching and plowing treatment respectively; $\mathbf{C}$ and $\mathbf{D}$ are the fresh weight of rice root for mulching and plowing treatment respectively.

Table 2. Comparison of root shoot ratio under different straw incorporation treatments.

\begin{tabular}{ccccccc}
\hline & $\mathbf{1 2} \mathrm{d}$ & & $\mathbf{5 6} \mathrm{d}$ & $\mathbf{7 5 ~ d}$ \\
\hline $\mathrm{MU}_{0}$ & $0.34 \pm 0.04$ & $\mathrm{a}$ & $0.44 \pm 0.04$ & $\mathrm{~b}$ & $0.21 \pm 0.01$ & $\mathrm{~d}$ \\
$\mathrm{MU}_{1}$ & $0.33 \pm 0.02$ & $\mathrm{~b}$ & $0.43 \pm 0.02$ & $\mathrm{c}$ & $0.22 \pm 0.02$ & $\mathrm{c}$ \\
$\mathrm{MU}_{2}$ & $0.32 \pm 0.02$ & $\mathrm{c}$ & $0.44 \pm 0.02$ & $\mathrm{~b}$ & $0.27 \pm 0.02$ & $\mathrm{~b}$ \\
$\mathrm{MU}_{3}$ & $0.30 \pm 0.01$ & $\mathrm{~d}$ & $0.45 \pm 0.01$ & $\mathrm{a}$ & $0.29 \pm 0.02$ & $\mathrm{a}$ \\
$\mathrm{PL}_{0}$ & $0.31 \pm 0.02$ & $\mathrm{a}$ & $0.51 \pm 0.02$ & $\mathrm{a}$ & $0.22 \pm 0.03$ & $\mathrm{~d}$ \\
$\mathrm{PL}_{1}$ & $0.28 \pm 0.03$ & $\mathrm{~b}$ & $0.48 \pm 0.03$ & $\mathrm{c}$ & $0.25 \pm 0.01$ & $\mathrm{c}$ \\
$\mathrm{PL}_{2}$ & $0.26 \pm 0.03$ & $\mathrm{c}$ & $0.48 \pm 0.03$ & $\mathrm{c}$ & $0.27 \pm 0.01$ & $\mathrm{~b}$ \\
$\mathrm{PL}_{3}$ & $0.24 \pm 0.05$ & $\mathrm{~d}$ & $0.49 \pm 0.05$ & $\mathrm{~b}$ & $0.28 \pm 0.02$ & $\mathrm{a}$ \\
\hline
\end{tabular}

$\mathrm{MU}_{0}, \mathrm{MU}_{1}, \mathrm{MU}_{2}$, and $\mathrm{MU}_{3}$ represent $0.0 \mathrm{t} / \mathrm{hm}^{2}, 1.5 \mathrm{t} / \mathrm{hm}^{2}, 3.0 \mathrm{t} / \mathrm{hm}^{2}$, and $4.5 \mathrm{t} / \mathrm{hm}^{2}$ of straw, respectively, which were incorporated in the soil by a mulching method. Whereas $\mathrm{PL}_{0}, \mathrm{PL}_{1}, \mathrm{PL}_{2}$, and $\mathrm{PL}_{3}$ represent $0.0 \mathrm{t} / \mathrm{hm}^{2}, 1.5 \mathrm{t} / \mathrm{hm}^{2}$, $3.0 \mathrm{t} / \mathrm{hm}^{2}$, and $4.5 \mathrm{t} / \mathrm{hm}^{2}$ of straw, respectively, which were incorporated in soil by a plowing method.

\subsection{Impacts of Straw Incorporation on the Dynamics of White Root}

The straw incorporation, either by mulching or plowing, produced negative impacts on the number and fresh weight of white roots during the early stage (0-36 days after transplanting) of rice growth (Figure 5). Compared with $\mathrm{MU}_{0}$, the length of white root of $\mathrm{MU}_{1}, \mathrm{MU}_{2}$, and $\mathrm{MU}_{3}$ decreased $9(p<0.05), 3$, and $13 \mathrm{~cm} / \mathrm{d}(p<0.05)$, with the reduction in fresh weight of $0.06(p<0.05), 0.03$, and $0.12 \mathrm{~g} / \mathrm{d}(p<0.05)$, respectively; the length of white root of $\mathrm{PL}_{1}, \mathrm{PL}_{2}$, and $\mathrm{PL}_{3}$ reduced 1,2 , and $4 \mathrm{~cm} / \mathrm{d}$ $(p<0.05)$, respectively, compared to $\mathrm{PL}_{0}$ and decreased in fresh weight of $0.01,0.05$, and $0.01 \mathrm{~g} / \mathrm{d}$, respectively, compared to $\mathrm{PL}_{0}$. These results indicate that straw-returning hindered the generation of new roots during the early stage of rice growth. Further analysis of root distribution (Supplementary Materials) showed that straw incorporation by mulching produced a significant negative impact on the length of white root in the $0-10 \mathrm{~cm}$ soil layer, while straw incorporation by plowing caused a negative impact on the white root in the 10-30 cm soil layer.

During the late stage of rice growth (56-75 days after transplanting), the impacts of straw-returning on the length and fresh weight of the white root were different between different straw-returning methods. In comparison of $\mathrm{MU}_{0}$, the length of white root of $\mathrm{MU}_{1}, \mathrm{MU}_{2}$, and $\mathrm{MU}_{3}$ increased $9(p<0.05)$, $13(p<0.05)$, and $8 \mathrm{~cm} / \mathrm{d}(p<0.05)$, with the increase in fresh weight of $0.34(p<0.05), 0.38(p<0.05)$, 
and $0.32 \mathrm{~g} / \mathrm{d}(p<0.05)$, respectively; while the root length of $\mathrm{PL}_{1}, \mathrm{PL}_{2}$, and $\mathrm{PL}_{3}$ increased $87(p<0.05)$, $105(p<0.05)$, and $112 \mathrm{~cm} / \mathrm{d}(p<0.05)$, respectively, compared with $\mathrm{PL}_{0}$, and increased in fresh weight of 0.25 ( $p<0.05), 0.45(p<0.05)$, and $0.65 \mathrm{~g} / \mathrm{d}(p<0.05)$, respectively, compared with $\mathrm{PL}_{0}$. Further analysis of root distribution (Supplementary Materials) showed that straw incorporation by mulching produced a negative impact on the length of white root in $0-10 \mathrm{~cm}$ soil layer; while this negative impact existed in the $0-10 \mathrm{~cm}$ and $30-50 \mathrm{~cm}$ soil layer for straw incorporation by plowing treatments.
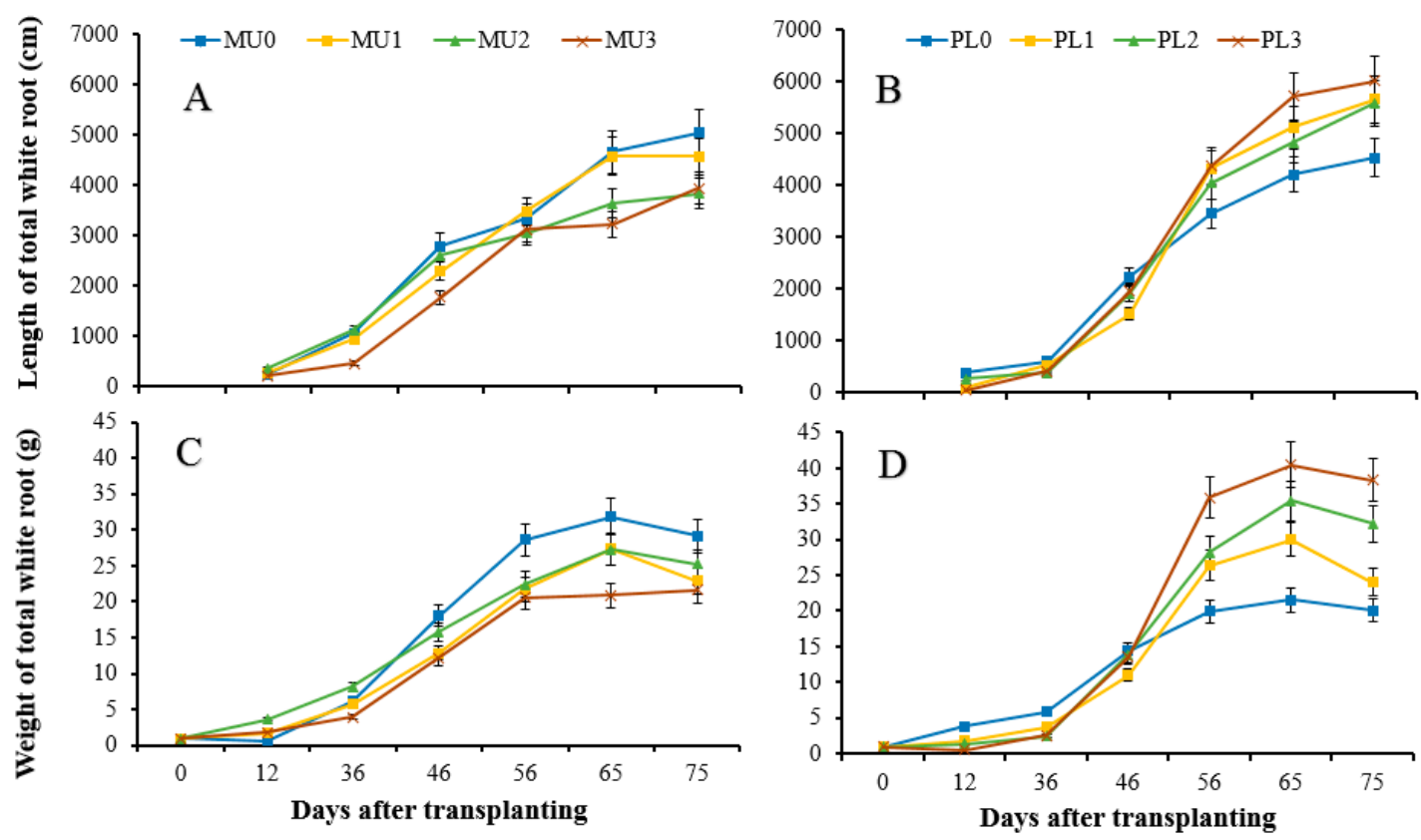

Figure 5. Comparison of total length and weight of white root in rice fields under different oilseed rape straw-returning treatments. $\mathrm{MU}_{0}, \mathrm{MU}_{1}, \mathrm{MU}_{2}$, and $\mathrm{MU}_{3}$ represent $0.0 \mathrm{t} / \mathrm{hm}^{2}, 1.5 \mathrm{t} / \mathrm{hm}^{2}, 3.0 \mathrm{t} / \mathrm{hm}^{2}$, and $4.5 \mathrm{t} / \mathrm{hm}^{2}$ of straw, respectively, which were incorporated in the soil by a mulching method. Whereas $\mathrm{PL}_{0}, \mathrm{PL}_{1}, \mathrm{PL}_{2}$, and $\mathrm{PL}_{3}$ represent $0.0 \mathrm{t} / \mathrm{hm}^{2}, 1.5 \mathrm{t} / \mathrm{hm}^{2}, 3.0 \mathrm{t} / \mathrm{hm}^{2}$, and $4.5 \mathrm{t} / \mathrm{hm}^{2}$ of straw, respectively, which were incorporated in the soil by a plowing method. A and $\mathbf{B}$ are the total length of white root under mulching and plowing treatment respectively; $\mathbf{C}$ and $\mathbf{D}$ are the fresh weight of white root for mulching and plowing treatment respectively.

\subsection{Impacts of Straw Incorporation on Root Bleeding}

Straw returned through mulching or plowing induced a negative impact on the bleeding intensity of rice roots during the early stage (0-36 days after transplanting) of rice growth (Figure 6). Compared with $\mathrm{MU}_{0}$, bleeding intensity of $\mathrm{MU}_{1}, \mathrm{MU}_{2}$, and $\mathrm{MU}_{3}$ decreased $0.3(p<0.05), 0.9(p<0.05)$, and 2.1 $(p<0.05) \mathrm{mg} /$ (plant.d) respectively; while the bleeding intensity of $\mathrm{PL}_{1}, \mathrm{PL}_{2}$, and $\mathrm{PL}_{3}$ reduced $0.1,0.9$, and $1.3(p<0.05) \mathrm{mg} /($ plant $\cdot \mathrm{d})$, respectively, compared with $\mathrm{PL}_{0}$. These results indicated that straw incorporation decreased the activity of rice roots during the early stage of rice growth.

At the later stage of rice growth (56-75 days after rice transplanting) the bleeding intensity of $\mathrm{MU}_{1}, \mathrm{MU}_{2}$, and $\mathrm{MU}_{3}$ decreased $4.9(p<0.05), 7.4(p<0.05)$, and $9.4(p<0.05) \mathrm{mg} /($ plant $\cdot \mathrm{d})$, respectively, compared with $\mathrm{MU}_{0}$; while it increased $0.9,1.1$, and $3.0 \mathrm{mg} /($ plant $\cdot \mathrm{d})$ of $\mathrm{PL}_{1}, \mathrm{PL}_{2}$, and $\mathrm{PL}_{3}(p<0.05)$, respectively, compared with $\mathrm{PL}_{0}$. These results specified that straw returning by plowing is better for increasing root activity during 56-75 days after rice transplanting compared with straw returning by mulching.

Straw returned by mulching or plowing caused the reduction of SS, GPT, GOT, and GS, in comparison to no straw-returning treatments during 36 days after rice transplanting. Compared with $\mathrm{MU}_{0}$, the SS, GPT, GOT, and GS of $\mathrm{MU}_{3}$ reduced $17.4 \%, 14.7 \%, 8.7 \%$, and $34.6 \%$, and $\mathrm{PL}_{3}$ reduced $22.6 \%$, $13.6 \%, 9.6 \%$, and $25.5 \%$, respectively, in comparison to $\mathrm{PL}_{0}$. These results provide some physiological reasons as to why straw-returning hindered root growth during the early stage. Also, these results 
explained why nitrogen fertilizer cannot relieve the slow revive and growth of roots in excessive straw-incorporating fields during the early stage of rice growth.
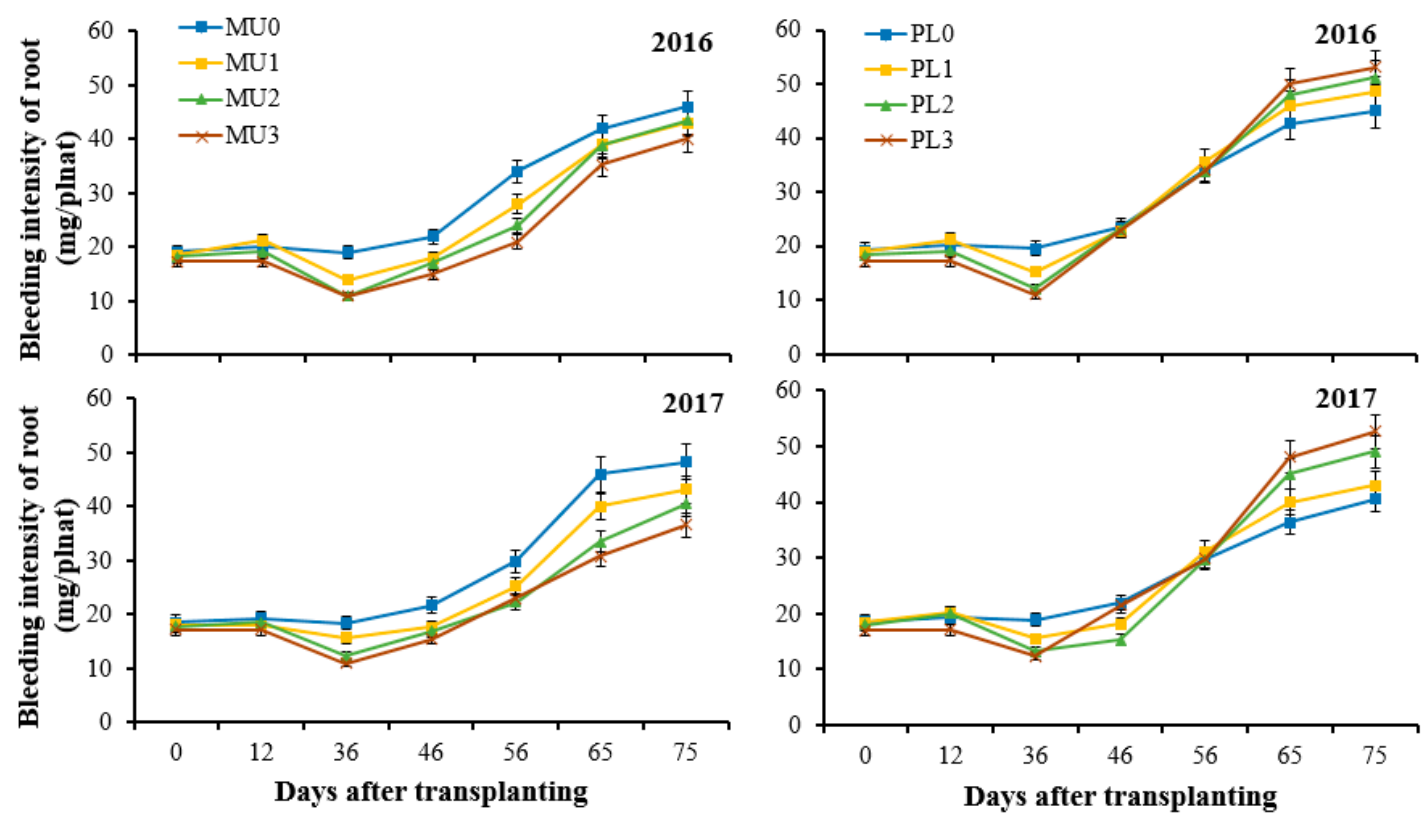

Figure 6. Dynamic changing of the bleeding intensity of rice roots under different straw incorporation treatments. $\mathrm{MU}_{0}, \mathrm{MU}_{1}, \mathrm{MU}_{2}$, and $\mathrm{MU}_{3}$ represent $0.0 \mathrm{t} / \mathrm{hm}^{2}, 1.5 \mathrm{t} / \mathrm{hm}^{2}, 3.0 \mathrm{t} / \mathrm{hm}^{2}$, and $4.5 \mathrm{t} / \mathrm{hm}^{2}$ of straw, respectively, which were incorporated in the soil by a mulching method. Whereas $\mathrm{PL}_{0}, \mathrm{PL}_{1}$, $\mathrm{PL}_{2}$, and $\mathrm{PL}_{3}$ represent $0.0 \mathrm{t} / \mathrm{hm}^{2}, 1.5 \mathrm{t} / \mathrm{hm}^{2}, 3.0 \mathrm{t} / \mathrm{hm}^{2}$, and $4.5 \mathrm{t} / \mathrm{hm}^{2}$ of straw, respectively, which were incorporated in the soil by a plowing method.

SS, GPT, GOT, and GS all appeared with an ascending trend at 56 days after rice transplanting compared with that at 36 days after rice transplanting (Table 3). Compared with $\mathrm{MU}_{0}$, the SS, GPT, GOT, and GS of straw returning treatments $\left(\mathrm{MU}_{1}, \mathrm{MU}_{2}\right.$, and $\left.\mathrm{MU}_{3}\right)$ reduced significantly, and its reduction rate became higher and higher from $\mathrm{MU}_{1}$ to $\mathrm{MU}_{3}$. However, compared with $\mathrm{PL}_{0}$, the $\mathrm{SS}$, GPT, GOT, and GS of straw returning treatments $\left(\mathrm{PL}_{1}, \mathrm{PL}_{2}\right.$, and $\left.\mathrm{PL}_{3}\right)$ all increased significantly, and its increasing rate becomes higher and higher from $\mathrm{PL}_{1}$ to $\mathrm{PL}_{3}$. These results indicated that with the time going on, the impacts of straw-returning on the roots activity were relieved. Compared with straw mulching, straw returning by plowing was better for increasing the activity of nitrogen invertase in the roots during the tillering stage.

Table 3. The content of soluble saccharide and the activity of nitrogen invertase in rice roots under different straw incorporation treatments.

\begin{tabular}{cccccc}
\hline DFP & TRT & SS (\%) & GPT $(\mu \mathbf{m o l} /(\mathbf{g} \cdot \mathbf{h}))$ & GOT $(\mu \mathbf{m o l} /(\mathbf{g} \cdot \mathbf{h}))$ & GS $(\mu \mathbf{m o l} /(\mathbf{g} \cdot \mathbf{h}))$ \\
\hline \multirow{6}{*}{36} & $\mathrm{MU}_{0}$ & $1.84 \pm 0.08 \mathrm{a}$ & $2.53 \pm 0.07 \mathrm{a}$ & $5.71 \pm 0.06 \mathrm{a}$ & $17.64 \pm 0.09 \mathrm{a}$ \\
& $\mathrm{MU}_{1}$ & $1.72 \pm 0.11 \mathrm{~b}$ & $2.48 \pm 0.06 \mathrm{ab}$ & $5.64 \pm 0.05 \mathrm{~b}$ & $15.21 \pm 0.08 \mathrm{~b}$ \\
& $\mathrm{MU}_{2}$ & $1.61 \pm 0.09 \mathrm{bc}$ & $2.46 \pm 0.06 \mathrm{~b}$ & $5.02 \pm 0.08 \mathrm{c}$ & $13.62 \pm 0.07 \mathrm{c}$ \\
& $\mathrm{MU}_{3}$ & $1.52 \pm 0.09 \mathrm{c}$ & $2.31 \pm 0.09 \mathrm{c}$ & $4.87 \pm 0.07 \mathrm{~d}$ & $11.54 \pm 0.07 \mathrm{~d}$ \\
& $\mathrm{PL}_{0}$ & $1.86 \pm 0.09 \mathrm{a}$ & $2.51 \pm 0.07 \mathrm{a}$ & $5.73 \pm 0.09 \mathrm{a}$ & $17.65 \pm 0.09 \mathrm{a}$ \\
& $\mathrm{PL}_{1}$ & $1.76 \pm 0.08 \mathrm{~b}$ & $2.45 \pm 0.08 \mathrm{a}$ & $5.51 \pm 0.07 \mathrm{~b}$ & $16.28 \pm 0.11 \mathrm{~b}$ \\
& $\mathrm{PL}_{2}$ & $1.51 \pm 0.07 \mathrm{c}$ & $2.35 \pm 0.07 \mathrm{~b}$ & $5.26 \pm 0.08 \mathrm{c}$ & $14.02 \pm 0.09 \mathrm{c}$ \\
& $\mathrm{PL}_{3}$ & $1.44 \pm 0.08 \mathrm{c}$ & $2.27 \pm 0.08 \mathrm{c}$ & $4.95 \pm 0.07 \mathrm{~d}$ & $13.15 \pm 0.10 \mathrm{~d}$ \\
\hline
\end{tabular}


Table 3. Cont.

\begin{tabular}{cccccc}
\hline DFP & TRT & SS (\%) & GPT $(\mu \mathbf{m o l} /(\mathbf{g} \cdot \mathbf{h}))$ & GOT $(\mu \mathbf{m o l} /(\mathbf{g} \cdot \mathbf{h}))$ & GS $(\mu \mathbf{m o l} /(\mathbf{g} \cdot \mathbf{h}))$ \\
\hline & $\mathrm{MU}_{0}$ & $2.05 \pm 0.08 \mathrm{a}$ & $3.04 \pm 0.07 \mathrm{a}$ & $5.86 \pm 0.08 \mathrm{a}$ & $18.18 \pm 0.12 \mathrm{a}$ \\
& $\mathrm{MU}_{1}$ & $1.99 \pm 0.06 \mathrm{ab}$ & $2.98 \pm 0.08 \mathrm{ab}$ & $5.72 \pm 0.08 \mathrm{~b}$ & $18.02 \pm 0.09 \mathrm{a}$ \\
& $\mathrm{MU}_{2}$ & $1.95 \pm 0.08 \mathrm{~b}$ & $2.95 \pm 0.05 \mathrm{~b}$ & $5.65 \pm 0.07 \mathrm{bc}$ & $17.98 \pm 0.12 \mathrm{ab}$ \\
56 & $\mathrm{MU}_{3}$ & $1.86 \pm 0.07 \mathrm{c}$ & $2.73 \pm 0.06 \mathrm{c}$ & $5.59 \pm 0.07 \mathrm{c}$ & $17.84 \pm 0.09 \mathrm{~b}$ \\
& $\mathrm{PL}_{0}$ & $2.08 \pm 0.06 \mathrm{~b}$ & $3.01 \pm 0.08 \mathrm{~d}$ & $5.78 \pm 0.08 \mathrm{c}$ & $18.24 \pm 0.08 \mathrm{~b}$ \\
& $\mathrm{PL}_{1}$ & $2.10 \pm 0.08 \mathrm{~b}$ & $3.14 \pm 0.06 \mathrm{c}$ & $5.86 \pm 0.09 \mathrm{bc}$ & $18.58 \pm 0.07 \mathrm{~b}$ \\
& $\mathrm{PL}_{2}$ & $2.16 \pm 0.06 \mathrm{ab}$ & $3.27 \pm 0.07 \mathrm{~b}$ & $5.94 \pm 0.08 \mathrm{ab}$ & $18.75 \pm 0.11 \mathrm{ab}$ \\
& $\mathrm{PL}_{3}$ & $2.23 \pm 0.06 \mathrm{a}$ & $3.46 \pm 0.08 \mathrm{a}$ & $5.98 \pm 0.07 \mathrm{a}$ & $19.02 \pm 0.12 \mathrm{a}$ \\
\hline
\end{tabular}

In each column, values followed by different letters are significantly different at $p<0.05$ using Fisher's LSD test. DFP means days after transplanting of rice, TRT was treatment; SS was the soluble saccharide; GOT was the activity of glutamic-oxalacetic transaminase; GPT was the activity of glutamic-pyruvic transaminase; GS was the activity of glutamine synthetase.

\subsection{Impacts of Straw Returning on Rice Yield and Its Component}

Straw returning, either by mulching or by plowing, increased grain yield by increasing panicles of each plant, spikelet per panicle, and 1000-grain weight, in comparison to no straw returning treatments (Table 4). The grain yield of $\mathrm{MU}_{2}$ and $\mathrm{MU}_{3}$ increased $1.11(p<0.05)$ and $0.79(p<0.05) \mathrm{t} / \mathrm{hm}^{2}$ in comparison to $\mathrm{MU}_{0}$; the grain yield of $\mathrm{PL}_{2}$ and $\mathrm{PL}_{3}$ increased $1.36(p<0.05)$ and $1.10(p<0.05) \mathrm{t} / \mathrm{hm}^{2}$ compared to $\mathrm{PL}_{0}$. Compared with $\mathrm{MU}_{0}, \mathrm{MU}_{2}$ and $\mathrm{MU}_{3}$ increased 0.77 and 0.91 in panicle per plant, 0.71 and $0.72 \mathrm{~g}$ in 1000-grain weight, and 29.02 and 28.93 spikelets per panicle; compared with $\mathrm{PL}_{0}$, $\mathrm{PL}_{2}$ and $\mathrm{PL}_{3}$ increased 3.63 and 3.88 in panicle per plant, 0.59 and $0.24 \mathrm{~g}$ in 1000 grain weight, and 32.40 and 31.01 spikelets per panicle.

Table 4. Comparison of the rice yield and its component for different straw incorporation treatments during 2016 and 2017.

\begin{tabular}{cccccccc}
\hline Year & Treatment & $\begin{array}{c}\text { Panicle } \\
\text { per Plant }\end{array}$ & $\begin{array}{c}\text { 1000 Grain } \\
\text { Weight (g) }\end{array}$ & $\begin{array}{c}\text { Spikelet } \\
\text { Fertility }\end{array}$ & $\begin{array}{c}\text { Spikelet per } \\
\text { Panicle }\end{array}$ & $\begin{array}{c}\text { Yield } \\
\left(\mathbf{t} / \mathbf{h m} \mathbf{2}^{\mathbf{}}\right)\end{array}$ & $\begin{array}{c}\text { Yield per Plot } \\
\text { (kg) }\end{array}$ \\
\hline \multirow{6}{*}{2016} & $9.74 \mathrm{a}$ & $29.26 \mathrm{~b}$ & $0.92 \mathrm{~b}$ & $255.54 \mathrm{~b}$ & $7.54 \mathrm{~b}$ & $29.94 \mathrm{c}$ \\
& $\mathrm{MU}_{0}$ & $7.38 \mathrm{~b}$ & $29.24 \mathrm{~b}$ & $0.94 \mathrm{a}$ & $258.15 \mathrm{~b}$ & $7.98 \mathrm{ab}$ & $31.18 \mathrm{~b}$ \\
& $\mathrm{MU}_{1}$ & $10.19 \mathrm{a}$ & $29.99 \mathrm{a}$ & $0.94 \mathrm{a}$ & $284.97 \mathrm{a}$ & $8.82 \mathrm{a}$ & $34.34 \mathrm{a}$ \\
& $\mathrm{MU}_{2}$ & $10.38 \mathrm{a}$ & $29.54 \mathrm{ab}$ & $0.93 \mathrm{ab}$ & $283.62 \mathrm{a}$ & $8.49 \mathrm{a}$ & $33.21 \mathrm{a}$ \\
\cline { 2 - 7 } & $\mathrm{MU}_{3}$ & $9.82 \mathrm{~b}$ & $29.27 \mathrm{~b}$ & $0.93 \mathrm{ab}$ & $254.91 \mathrm{~b}$ & $7.67 \mathrm{~b}$ & $31.38 \mathrm{~b}$ \\
& $\mathrm{PL}_{0}$ & $11.20 \mathrm{~b}$ & $29.23 \mathrm{~b}$ & $0.94 \mathrm{a}$ & $261.48 \mathrm{~b}$ & $7.98 \mathrm{ab}$ & $31.18 \mathrm{~b}$ \\
& $\mathrm{PL}_{1}$ & $13.37 \mathrm{a}$ & $29.90 \mathrm{a}$ & $0.94 \mathrm{a}$ & $286.68 \mathrm{a}$ & $8.95 \mathrm{a}$ & $34.79 \mathrm{a}$ \\
& $\mathrm{PL}_{2}$ & $13.65 \mathrm{a}$ & $29.56 \mathrm{ab}$ & $0.92 \mathrm{~b}$ & $285.87 \mathrm{a}$ & $8.67 \mathrm{a}$ & $33.82 \mathrm{a}$ \\
\hline \multirow{4}{*}{2017} & $\mathrm{PL}_{3}$ & $9.65 \mathrm{a}$ & $29.24 \mathrm{~b}$ & $0.91 \mathrm{c}$ & $254.55 \mathrm{~b}$ & $7.40 \mathrm{~b}$ & $29.46 \mathrm{~b}$ \\
& $\mathrm{MU}_{0}$ & $7.75 \mathrm{~b}$ & $29.24 \mathrm{~b}$ & $0.94 \mathrm{a}$ & $256.26 \mathrm{~b}$ & $7.54 \mathrm{ab}$ & $29.94 \mathrm{ab}$ \\
& $\mathrm{MU}_{1}$ & $10.74 \mathrm{a}$ & $29.92 \mathrm{a}$ & $0.93 \mathrm{ab}$ & $283.17 \mathrm{a}$ & $8.34 \mathrm{a}$ & $32.69 \mathrm{a}$ \\
& $\mathrm{MU}_{2}$ & $10.84 \mathrm{a}$ & $29.42 \mathrm{ab}$ & $0.92 \mathrm{bc}$ & $284.34 \mathrm{a}$ & $8.02 \mathrm{a}$ & $31.59 \mathrm{a}$ \\
\hline $\mathrm{MU}_{3}$ & $\mathrm{PL}_{0}$ & $9.72 \mathrm{~b}$ & $29.24 \mathrm{~b}$ & $0.91 \mathrm{~b}$ & $252.75 \mathrm{~b}$ & $7.38 \mathrm{~b}$ & $29.39 \mathrm{~b}$ \\
& $\mathrm{PL}_{1}$ & $11.25 \mathrm{~b}$ & $29.24 \mathrm{~b}$ & $0.94 \mathrm{a}$ & $257.07 \mathrm{~b}$ & $7.88 \mathrm{ab}$ & $31.11 \mathrm{~b}$ \\
& $\mathrm{PL}_{2}$ & $13.43 \mathrm{a}$ & $29.80 \mathrm{a}$ & $0.93 \mathrm{a}$ & $285.78 \mathrm{a}$ & $8.82 \mathrm{a}$ & $34.34 \mathrm{a}$ \\
& $\mathrm{PL}_{3}$ & $13.65 \mathrm{a}$ & $29.51 \mathrm{ab}$ & $0.92 \mathrm{ab}$ & $283.80 \mathrm{a}$ & $8.58 \mathrm{a}$ & $33.52 \mathrm{a}$ \\
\hline
\end{tabular}

In each column, values followed by different letters are significantly different at $p<0.05$ using Fisher's LSD test.

Straw returning by plowing increased more yield than straw returning by mulching. Compared with $\mathrm{MU}_{2}$, the yield of $\mathrm{PL}_{2}$ increased $0.31 \mathrm{t} / \mathrm{hm}^{2}$, and the yield of $\mathrm{PL}_{3}$ increased by $0.37 \mathrm{t} / \mathrm{hm} \mathrm{m}^{2}$ compared to $\mathrm{MU}_{3}$. These results showed that oilseed rape straw returning by plowing is more suitable for the oilseed rape-rice rotation system. 


\subsection{Correlation Analysis}

The length of total root, length of white root, activity of nitrogen invert enzyme, and amount of root bleeding all have some impacts on the rice yield and its components under straw incorporation conditions. However, their effective period was different (Table 5), and the total root length has a significant impact on yield, panicle per plant, and 1000-grain weight at the later stage of rice growth.

Table 5. Correlation analysis between root growth and rice yield.

\begin{tabular}{cccccccccc}
\hline \multirow{2}{*}{ Year } & \multirow{2}{*}{ Item } & \multicolumn{2}{c}{ Total Root Length } & \multicolumn{2}{c}{ Length of White Root } & \multicolumn{2}{c}{ Nitrogen Invert-Ase } & \multicolumn{2}{c}{ Root Bleeding } \\
\cline { 3 - 10 } & & $\mathbf{3 6 d}$ & $\mathbf{6 5 d}$ & $\mathbf{3 6 d}$ & $\mathbf{6 5 d}$ & $\mathbf{3 6 d}$ & $\mathbf{6 5 d}$ & $\mathbf{3 6 d}$ & $\mathbf{6 5 d}$ \\
\hline \multirow{6}{*}{$\mathbf{2 0 1 6}$} & Yield & -0.35 & $0.75^{*}$ & -0.40 & 0.07 & -0.49 & $0.77^{*}$ & $0.62^{*}$ & 0.21 \\
& EPP & -0.54 & $0.61^{*}$ & -0.38 & 0.45 & -0.45 & $0.75^{*}$ & -0.48 & $0.69^{*}$ \\
& GW & 0.07 & $0.65^{*}$ & 0.01 & -0.23 & -0.39 & 0.08 & -0.07 & $0.63^{*}$ \\
& SPP & -0.32 & 0.32 & $-0.66^{*}$ & $0.74^{*}$ & $-0.90^{*}$ & $0.88^{*}$ & $0.91^{*}$ & 0.01 \\
& SPF & 0.30 & 0.49 & 0.26 & 0.25 & 0.00 & 0.18 & -0.24 & 0.19 \\
\hline \multirow{2}{*}{$\mathbf{2 0 1 7}$} & Yield & 0.26 & $0.81^{*}$ & -0.35 & 0.13 & -0.38 & $0.65^{*}$ & $0.66^{*}$ & 0.32 \\
& EPP & -0.41 & $0.63^{*}$ & 0.15 & 0.37 & 0.12 & $0.71^{*}$ & -0.31 & $0.62^{*}$ \\
& GW & 0.15 & $0.66^{*}$ & -0.11 & 0.14 & -0.33 & -0.01 & 0.06 & $0.72^{*}$ \\
& SPP & -0.44 & 0.41 & $-0.62 *$ & $0.71 *$ & $-0.87^{*}$ & $0.88^{*}$ & $0.86^{*}$ & 0.13 \\
& SPF & 0.29 & 0.38 & 0.28 & 0.22 & -0.02 & 0.19 & 0.19 & 0.20 \\
\hline
\end{tabular}

The values shown are Pearson correlation coefficients, and significant correlations are indicated by * $(p<0.05)$. EPP, Panicle per plant; GW, 1000-grain weight; SPP, Spikelet per panicle; SPF, Spikelet fertility.

The length of white root, activity of nitrogen invert enzyme, and amount of root bleeding have a significant impact on spikelet per panicle. These outcomes suggested that root growth and its quality have a great impact on the rice yield in straw-returning fields.

Compared with 36 days of transplanting, there were more factors that had a significant relation to yield and the yield component at 65 days after transplanting (Table 5). These findings revealed that the effect of straw returning at the late stage contributed more to the rice yield in comparison to the early stage.

\section{Discussion}

\subsection{Impacts of Straw Returning on Root Growth}

After the returning of oilseed rape straw, the decomposition of straw under an anaerobic environment caused the oxygen content to reduce rapidly [21,22], and the reductive substance content increased dramatically in soil [23-26], which deteriorated the root growing environment in rice fields. Results of this research showed that root length, root weight, and root bleeding reduced significantly in straw-returning treatment compared with no straw-returning treatment, either by mulching or by plowing, during the early stage of rice growth. These results indicated that oilseed rape straw incorporation hindered the growth of roots during the early stage of rice growth. Furthermore, our investigation unveiled that straw returning by mulching induced a negative impact on new germinating roots in the $0-10 \mathrm{~cm}$ soil layer, and in the 10-30 $\mathrm{cm}$ soil layer for straw returning by a plowing method during the early stage of rice growth.

As time went by, due to the flooding ending and the slow process of straw decomposition, the oxygen content and the oxidation-reduction potential of the soil increased, which make a better environment for root growth [27-30]. The results of this research showed that after 56-75 days of rice transplanting, root length of straw mulching treatments $\left(\mathrm{MU}_{1}, \mathrm{MU}_{2}\right.$ and $\left.\mathrm{MU}_{3}\right)$ were not increased significantly in comparison to no straw-returning treatment $\left(\mathrm{MU}_{0}\right)$, while root lengths of the plowing treatments $\left(\mathrm{PL}_{1}, \mathrm{PL}_{2}\right.$, and $\left.\mathrm{PL}_{3}\right)$ were significantly higher than no straw-returning treatment $\left(\mathrm{PL}_{0}\right)$. Furthermore, this research found that root length and root weight of the straw mulching treatment was significantly lower than that of no straw-returning treatment in the $0-10 \mathrm{~cm}$ soil layer, while 
straw returning by plowing caused a significant increase of root length in the $0-30 \mathrm{~cm}$ soil layer, in comparison to $\mathrm{PL}_{0}$. These results demonstrated that straw incorporation by plowing produced more positive impacts on root growth than that by mulching during 56-75 days after rice transplanting.

\subsection{Impacts of Straw Returning on Tiller Growth and Yield of Hybrid Rice}

Straw incorporation caused deterioration of the soil environment, which leads to late revival and the reduction of tiller during the early stage of rice growth [11,31], while nutrients released from straw decomposition promoted tiller growth in the late stage of rice growth [5,32-34]. The reason for the negative impacts of straw incorporation on rice tiller is complex [35-37] and has been reported by many scientists [38-42]. The results of this research revealed that straw returning, either by mulching or by plowing, produced a negative impact on root length and weight during 0-36 days after rice transplanting. Furthermore, we have found that straw incorporation significantly reduced the activity of nitrogen invertase (GPT, GOT, and GS) in roots (Table 3); this may be due to the lower content of oxygen in the soil during 0-36 days after rice transplanting. Our findings suggested that the slow growth of roots and lower activity of nitrogen invertase are other reasons for late revival and slow growth of rice in straw-returning fields. This conclusion also explains why nitrogen fertilizer cannot speed up the rice growth during the early stage of rice growth in straw-returning fields.

Similar to Hu et al. [16] and Yang et al. [27], this research showed that the maximum tillers of all straw-returning treatments was higher than no straw-returning treatment. Moreover, this research confirmed that it was the recovery of roots and the increase of the activity of nitrogen invertase that promoted the tillers growth during 56-75 days of rice transplanting and the positive impacts of straw incorporation on tiller growth during 56-75 days of rice transplanting, and explained its reason from the perspective of root activity, root growth, and nitrogen invertase activity. These outcomes provided a more basic understanding of the impacts of straw incorporation on rice growth in the rice-rape rotation system.

Most previous reports have shown that straw incorporation increased grain yield [43-45], while other studies reported the negative impacts of straw returning on rice yield $[30,46]$. The results of this paper displayed that the variation of rice yield was affected by the amount and the method of oilseed rape straw returning. In comparison to no straw returning treatment $\left(\mathrm{MU}_{0}\right.$ and $\left.\mathrm{PL}_{0}\right)$, spikelet fertility, panicle per plant, and grain yield of $\mathrm{PL}_{1}$ did not increase significantly $(p>0.05)$; while of $\mathrm{MU}_{1}$ decreased significantly $(p<0.05)$. In a comparison of no straw returning treatment $\left(\mathrm{MU}_{0}\right.$ and $\left.\mathrm{PL}_{0}\right)$, the panicle per plant, spikelet per panicle, spikelet fertility, and grain yield of $\mathrm{MU}_{2}, \mathrm{MU}_{3}, \mathrm{PL}_{2}$, and $\mathrm{PL}_{3}$ increased significantly $(p<0.05)$. Compared with mulching, the grain yield of the plowing treatment was slightly higher. Considering the variation of rice yield, a reasonable amount of oilseed rape straw in the rice field is not more than $3.0 \mathrm{t} / \mathrm{hm}^{2}$, and straw returning by plowing is better than mulching in the Sichuan Basin area.

\section{Conclusions}

During the early stage (0-36 days after rice transplanting), oilseed rape straw returning either by mulching or by plowing produced a negative impact on tiller growth. This negative effect might cause lower root activity (white root amount, root bleeding amount) and lower activity of nitrogen invertase in roots in straw-returning fields. Oilseed rape straw returning by mulching performed a negative impact on new roots generating in the $0-10 \mathrm{~cm}$ soil layer; straw returning by plowing produced a negative impact on root growth in the 10-30 cm soil layer.

During the later stage (56-75 days after rice transplanting), oilseed rape straw returning produced some positive impacts on rice roots, which caused the yield of rice to increase in the straw-returning field. The variation of yield in the oilseed rape straw returning field is the balance of negative and positive factors that are produced by straw decomposing under an anaerobic environment. Considering the roots growth, rice yield, and dynamics of tillering, a reasonable amount of oilseed rape straw 
returned into rice filed is $3.0 \mathrm{t} / \mathrm{hm}^{2}$, and straw returning by plowing is a more appropriate method than mulching in the rice-rape rotation system in the Sichuan Basin area.

Supplementary Materials: The following are available online at http://www.mdpi.com/2073-4395/9/11/690/s1, Figure S1: Dynamic changes of root length in different soil layers under different straw incorporation treatments. $\mathrm{MU}_{0}, \mathrm{MU}_{1}, \mathrm{MU}_{2}, \mathrm{MU}_{3}$ represent $0.0 \mathrm{t} / \mathrm{hm}^{2}, 1.5 \mathrm{t} / \mathrm{hm}^{2}, 3.0 \mathrm{t} / \mathrm{hm}^{2}$ and $4.5 \mathrm{t} / \mathrm{hm}^{2}$ of straw respectively, which were incorporated in soil by mulching method. Whereas $\mathrm{PL}_{0}, \mathrm{PL}_{1}, \mathrm{PL}_{2}, \mathrm{PL}_{3}$ represent $0.0 \mathrm{t} / \mathrm{hm}^{2}, 1.5 \mathrm{t} / \mathrm{hm}^{2}, 3.0 \mathrm{t} / \mathrm{hm}^{2}$ and $4.5 \mathrm{t} / \mathrm{hm}^{2}$ of straw respectively, which were incorporated in soil by ploughing method, Table S1: Tiller dynamics of rice under different treatments during 2016 (data for Figure 2 in manuscript); Table S2: Tiller dynamics of rice under different treatments during 2017 (data for Figure 2 in manuscript); Table S3: Total weight of rice root under different straw returning treatments (data for Figure 4 in manuscript); Table S4: Total length of rice root under different straw returning treatments (data for Figure 4 in manuscript); Table S5: Total weight of white root under different straw returning treatments (data for Figure 5 in manuscript); Table S6: Total length of white root under different straw returning treatments (data for Figure 5 in manuscript); Table S7 Bleeding intensity of rice root under different straw incorporation treatments during 2016 (data for Figure 6 in manuscript); Table S8: Bleeding intensity of rice root under different straw incorporation treatments during 2016 (data for Figure 6 in manuscript); Table S9: The ANOVA analysis of the tillers and effective tillers.

Author Contributions: X.W. and Y.H. proposed the ideas, designed the experiments, and provided funding*, N.S. and C.Z. conducted the experiment and wrote the paper, H.W. and G.Y. analyzed the dada, Y.P., and F.R. reviewed paper.

Funding: This research received no external funding.

Acknowledgments: This work was supported by the National Science and Technology Innovation Project for Grain Enrichment and Efficiency (2017YFD0100206; 2016YFD0300210), the National Natural Science Foundation of China (31401347; 31601269), and the Sichuan Science and Technology Program (2018HH0039; 2018NZZJ001).

Conflicts of Interest: The authors declare no conflict of interest.

\section{References}

1. Li, H.; Dai, M.; Dai, S.; Dong, X. Current status and environment impact of direct straw return in China's cropland-A review. Ecotoxicol. Environ. Saf. 2018, 159, 293-300. [CrossRef]

2. Yuan, L.; Zhang, Z.; Cao, X.; Zhu, S.; Zhang, X.; Wu, L. Responses of rice production, milled rice quality and soil properties to various nitrogen inputs and rice straw incorporation under continuous plastic film mulching cultivation. Field Crop. Res. 2014, 155, 164-171. [CrossRef]

3. Totin, E.; Stroosnijder, L.; Agbossou, E. Mulching upland rice for efficient water management: A collaborative approach in Benin. Agric. Water Manag. 2013, 125, 71-80. [CrossRef]

4. Su, W.; Lu, J.; Wang, W.; Li, X.; Ren, T.; Cong, R. Influence of rice straw mulching on seed yield and nitrogen use efficiency of winter oilseed rape (Brassica napus L.) in intensive rice-oilseed rape cropping system. Field Crop. Res. 2014, 159, 53-61. [CrossRef]

5. Yin, H.; Zhao, W.; Li, T.; Cheng, X.; Liu, Q. Balancing straw returning and chemical fertilizers in China: Role of straw nutrient resources. Renew. Sustain. Energy Rev. 2018, 81, 2695-2702. [CrossRef]

6. Köbke, S.; Pfeiffer, B.; Senbayram, M.; Dittert, K.; Nacke, H. Post-harvest $\mathrm{N}_{2} \mathrm{O}$ and $\mathrm{CO}_{2}$ emissions related to plant residue incorporation of oilseed rape and barley straw depend on soil $\mathrm{NO}_{3}$-content. Soil. Till. Res. 2018, 179, 105-113. [CrossRef]

7. Krupnik, T.J.; Shennan, C.; Rodenburg, J. Yield, water productivity and nutrient balances under the System of Rice Intensification and Recommended Management Practices in the Sahel. Field Crop. Res. 2012, 130, 155-167. [CrossRef]

8. Zhang, J.; Hu, K.; Li, K.; Zheng, C.; Li, B. Simulating the effects of long-term discontinuous and continuous fertilization with straw return on crop yields and soil organic carbon dynamics using the DNDC model. Soil. Till. Res. 2017, 165, 302-314. [CrossRef]

9. Grant, C.A.; O’Donovan, J.T.; Blackshaw, R.E.; Harker, K.N.; Johnson, E.N.; Gan, Y.; Lafond, G.P.; May, W.E.; Turkington, T.K.; Lupwayi, N.Z.; et al. Residual effects of preceding crops and nitrogen fertilizer on yield and crop and soil $\mathrm{N}$ dynamics of spring wheat and canola in varying environments on the Canadian prairies. Field Crop. Res. 2016, 192, 86-102. [CrossRef]

10. Singh, G.; Jalota, S.K.; Singh, Y. Manuring and residue management effects on physical properties of a soil under the rice-wheat system in Punjab, India. Soil. Till. Res. 2007, 94, 229-238. [CrossRef] 
11. Xu, Y.; Nie, L.; Buresh, R.J.; Huang, J.; Cui, K.; Xu, B.; Gong, W.; Peng, S. Agronomic performance of late-season rice under different tillage, straw, and nitrogen management. Field Crop. Res. 2010, 115, 79-84. [CrossRef]

12. Dawe, D.; Dobermann, A.; Ladha, J.K.; Yadav, R.L.; Bao, L.; Gupta, R.K.; Lal, P.; Panaullah, G.; Sariam, O.; Singh, Y.; et al. Do organic amendments improve yield trends and profitability in intensive rice systems? Field Crop. Res. 2003, 83, 191-213. [CrossRef]

13. Becker, M.; Asch, F.; Maskey, S.L.; Pande, K.R.; Shah, S.C.; Shrestha, S. Effects of transition season management on soil $\mathrm{N}$ dynamics and system $\mathrm{N}$ balances in rice-wheat rotations of Nepal. Field Crop. Res. 2007, 103, 98-108. [CrossRef]

14. Zhang, J.; Hang, X.; Lamine, S.M.; Jiang, Y.; Afreh, D.; Qian, H.; Feng, X.; Zheng, C.; Deng, A.; Song, Z.; et al. Interactive effects of straw incorporation and tillage on crop yield and greenhouse gas emissions in double rice cropping system. Agric. Ecosyst. Environ. 2017, 250, 37-43. [CrossRef]

15. Wang, J.Y.; Jia, J.X.; Xiong, Z.Q.; Khalil, M.A.K.; Xing, G.X. Water regime-nitrogen fertilizer-straw incorporation interaction: Field study on nitrous oxide emissions from a rice agroecosystem in Nanjing, China. Agric. Ecosyst. Environ. 2011, 141, 437-446. [CrossRef]

16. Fan, J.B.; Zhang, Y.L.; Turner, D.; Duan, Y.H.; Wang, D.S.; Shen, Q.R. Root Physiological and Morphological Characteristics of Two Rice Cultivars with Different Nitrogen-Use Efficiency. Pedosphere 2010. [CrossRef]

17. Hu, X.; Fang, C.; Lu, L.; Hu, Z.; Shao, Y.; Zhu, Z. Determination of soluble sugar profile in rice. J. Chromatogr. B 2017, 1058, 19-23. [CrossRef]

18. Sax, S.M.; Moore, J.J.; Nino, H.V.; Edwards, D.J.; Annino, J.S. Glutamic Oxalacetic Transaminase (Colorimetric); MacDonald, R.P., Ed.; Elsevier: Amsterdam, The Netherlands, 1970.

19. Zhong, C.; Cao, X.; Bai, Z.; Zhang, J.; Zhu, L.; Huang, J.; Jin, Q. Plant Physiology and Biochemistry Nitrogen metabolism correlates with the acclimation of photosynthesis to short-term water stress in rice (Oryza sativa L.). Plant. Physiol. Biochem. 2018, 125, 52-62. [CrossRef]

20. Yu, X.Z.; Zhang, F.Z. Activities of nitrate reductase and glutamine synthetase in rice seedlings during cyanide metabolism. J. Hazard. Mater. 2012, 225-226, 190-194. [CrossRef]

21. Hu, N.; Wang, B.; Gu, Z.; Tao, B.; Zhang, Z.; Hu, S.; Zhu, L.; Meng, Y. Effects of different straw returning modes on greenhouse gas emissions and crop yields in a rice-wheat rotation system. Agric. Ecosyst. Environ. 2016, 223, 115-122. [CrossRef]

22. Zhou, T.; Pan, G.; Li, L.; Zhang, X.; Zheng, J.; Zheng, J.; Chang, A. Changes in greenhouse gas evolution in heavy metal polluted paddy soils with rice straw return: A laboratory incubation study. Eur. J. Soil Biol. 2014, 63, 1-6. [CrossRef]

23. Zhang, Z.S.; Guo, L.J.; Liu, T.Q.; Li, C.F.; Cao, C.G. Effects of tillage practices and straw returning methods on greenhouse gas emissions and net ecosystem economic budget in rice-wheat cropping systems in central China. Atmos. Environ. 2015, 122, 636-644. [CrossRef]

24. Chen, Z.; Wang, H.; Liu, X.; Zhao, X.; Lu, D.; Zhou, J.; Li, C. Changes in soil microbial community and organic carbon fractions under short-term straw return in a rice-wheat cropping system. Soil. Till. Res. 2017, 165, 121-127. [CrossRef]

25. Xu, X.; Pang, D.; Chen, J.; Luo, Y.; Zheng, M.; Yin, Y.; Li, Y.; Li, Y.; Wang, Z. Straw return accompany with low nitrogen moderately promoted deep root. Field Crop. Res. 2018, 221, 71-80. [CrossRef]

26. Zhu, H.; Zhong, H.; Wu, J. Chemosphere Incorporating rice residues into paddy soils affects methylmercury accumulation in rice. Chemosphere 2016, 152, 259-264. [CrossRef]

27. Thakur, A.K.; Mandal, K.G.; Mohanty, R.K.; Ambast, S.K. Rice root growth, photosynthesis, yield and water productivity improvements through modifying cultivation practices and water management. Agric. Water Manag. 2018, 206, 67-77. [CrossRef]

28. Linh, T.B.; Sleutel, S.; Vo Thi, G.; Le Van, K.; Cornelis, W.M. Deeper tillage and root growth in annual rice-upland cropping systems result in improved rice yield and economic profit relative to rice monoculture. Soil. Till. Res. 2015, 154, 44-52. [CrossRef]

29. Yang, C.; Yang, L.; Yang, Y.; Ouyang, Z. Rice root growth and nutrient uptake as influenced by organic manure in continuously and alternately flooded paddy soils. Agric. Water Manag. 2004, 70, 67-81. [CrossRef]

30. Xue, B.; Huang, L.; Huang, Y.; Yin, Z.; Li, X.; Lu, J. Effects of organic carbon and iron oxides on soil aggregate stability under different tillage systems in a rice-rape cropping system. Catena 2019, 177, 1-12. [CrossRef] 
31. Yang, H.; Zhai, S.; Li, Y.; Zhou, J.; He, R.; Liu, J.; Xue, Y.; Meng, Y. Waterlogging reduction and wheat yield increase through long-term ditch-buried straw return in a rice-Wheat rotation system. Field Crop. Res. 2017, 209, 189-197. [CrossRef]

32. Yang, H.; Yang, B.; Dai, Y.; Xu, M.; Koide, R.T.; Wang, X.; Liu, J.; Bian, X. Soil nitrogen retention is increased by ditch-buried straw return in a rice-wheat rotation system. Eur. J. Agron. 2015, 69, 52-58. [CrossRef]

33. Bai, Y.L.; Wang, L.; Lu, Y.L.; Yang, L.P.; Zhou, L.P.; Ni, L.; Cheng, M.F. Effects of long-term full straw return on yield and potassium response in wheat-maize rotation. J. Integr. Agric. 2015. [CrossRef]

34. Nie, J.; Chen, X.; Zhou, J.; Du, C.; Wang, H. Effect of Long-Term Rice Straw Return on Soil Glomalin, Carbon and Nitrogen. Pedosphere 2007, 17, 295-302. [CrossRef]

35. Chico-Santamarta, L.; Humphries, A.C.; Chaney, K.; White, D.R.; Magan, N.; Godwin, R.J. Microbial changes during the on-farm storage of canola (oilseed rape) straw bales and pellets. Biomass Bioenergy 2011, 35, 2939-2949. [CrossRef]

36. Kimber, R. Phytotoxicity from plant residues. I. The influence of rotted wheat straw on seedling growth. Aust. J. Agric. Res. 2004. [CrossRef]

37. Hou, P.; Li, G.; Wang, S.; Jin, X.; Yang, Y.; Chen, X.; Ding, C.; Liu, Z.; Ding, Y. Methane emissions from rice fields under continuous straw return in the middle-lower reaches of the Yangtze River. J. Environ. Sci-China 2013, 25, 1874-1881. [CrossRef]

38. Yang, L.; Bai, J.; Zeng, N.; Zhou, X.; Liao, Y.; Lu, Y.; Rees, R.M.; Nie, J.; Cao, W. Diazotroph abundance and community structure are reshaped by straw return and mineral fertilizer in rice-rice-green manure rotation. Appl. Soil Ecol. 2019, 136, 11-20. [CrossRef]

39. Liu, Y.R.; Dong, J.X.; Han, L.L.; Zheng, Y.M.; He, J.Z. Influence of rice straw amendment on mercury methylation and nitrification in paddy soils. Environ. Pollut. 2016, 209, 53-59. [CrossRef]

40. Yu, Y.; Wu, M.; Petropoulos, E.; Zhang, J.; Nie, J.; Liao, Y.; Li, Z.; Lin, X.; Feng, Y. Responses of paddy soil bacterial community assembly to different long-term fertilizations in southeast China. Sci. Total. Environ. 2019, 656, 625-633. [CrossRef]

41. Azam, F.; Lodhi, A.; Ashraf, M. Availability of soil and fertilizer nitrogen to wetland rice following wheat straw amendment. Biol. Fert. Soils. 1991, 11, 97-100. [CrossRef]

42. Lu, S.; Han, S.; Du, Y.; Liu, H.; Nie, H.; Luo, X.; Huang, Q. The shift of sulfate-reducing bacterial communities from the upland to the paddy stage in a rapeseed-rice rotation system, and the eff ect from the long- term straw returning. Appl. Soil Ecol. 2018, 124, 124-130. [CrossRef]

43. Ding, W.; Xu, X.; He, P.; Ullah, S.; Zhang, J.; Cui, Z.; Zhou, W. Improving yield and nitrogen use efficiency through alternative fertilization options for rice in China: A meta-analysis. Field Crop. Res. 2018, 227, 11-18. [CrossRef]

44. Jin, Z.J.; Li, L.Q.; Liu, X.Y.; Pan, G.X.; Qaiser, H.; Liu, Y.Z. Impact of Long-Term Fertilization on Community Structure of Ammonia Oxidizing and Denitrifying Bacteria Based on amoA and nirK Genes in a Rice Paddy from Tai Lake Region, China. J. Integr. Agric. 2014, 13, 2286-2298. [CrossRef]

45. Pan, G.; Zhou, P.; Li, Z.; Smith, P.; Li, L.; Qiu, D.; Zhang, X.; Xu, X.; Shen, S.; Chen, X. Combined inorganic/organic fertilization enhances $\mathrm{N}$ efficiency and increases rice productivity through organic carbon accumulation in a rice paddy from the Tai Lake region, China. Agric. Ecosyst. Environ. 2009, 131, $274-280$. [CrossRef]

46. Qin, X.; Wang, H.; Liu, C.; Li, J.; Wan, Y.; Gao, Q.; Fan, F.; Liao, Y. Long-term effect of biochar application on yield-scaled greenhouse gas emissions in a rice paddy cropping system: A four-year case study in south China. Sci. Total Environ. 2016, 570, 1390-1401. [CrossRef]

(C) 2019 by the authors. Licensee MDPI, Basel, Switzerland. This article is an open access article distributed under the terms and conditions of the Creative Commons Attribution (CC BY) license (http://creativecommons.org/licenses/by/4.0/). 